\title{
PENGARUH PROFITABILITAS, LEVERAGE DAN UKURAN PERUSAHAAN TERHADAP NILAI PERUSAHAAN
}

\author{
Dwi Rachmawati dan Dahlia Br. Pinem \\ pinem_dahlia@yahoo.com \\ Fakultas Ekonomi UPN "Veteran" Jakarta \\ Jl. R.S. Fatmawati Pondok Labu, Jakarta Selatan - 12450
}

\begin{abstract}
This study was conducted to examine the effect of Profitability, Leverage and Firm Size on Firm Value at the Company's manufacturing base and chemical industry sectors listed in Indonesia Stock Exchange during the years 2013 to 2014. The population in this study amounted to 55 companies manufacturing industrial sector basic and chemical contained in the Indonesia Stock Exchange during 2013 to 2014. Samples were obtained in this study of 52 samples selected by purposive sampling method. After outlier data, which eventually resulted 48 samples to be analyzed and tested. Data were tested using multiple linear regression method. These results showed that: Provitability significant positive effect on firm value, Leverage not significant effect on firm value and Firm Size positive effect on firm value.
\end{abstract}

Keyword: Profitability, Leverage, Firm Size and Firm Value

\section{PENDAHULUAN}

\section{Latar Belakang Penelitian}

Suatu perusahaan yang didirikan pasti untuk dapat mencapai tujuantujuan yang telah ditetapkan dengan melakukan strategi-strategi untuk mencapainya. 'Tujuan perusahaan adalah memaksimalkan nilai perusahaan. Salah satu faktor yang mempengaruhi harga saham adalah kemampuan perusahaan membayar dividen. Nilai perusahaan dapat dilihat dari besarnya kemampuan perusahaan membayar dividen. Besarnya dividen akan mempengaruhi harga sahamnya. Apabila dividen yang dibayar tinggi, maka harga saham cenderung tinggi sehingga nilai perusahaan juga tinggi dan sebaliknya' (Harjito \& Martono 2013, hlm. 3).
Pemegang saham sebagai pemilik perusahaan biasanya menginvestasikan dananya dengan tujuan untuk memperoleh dividen yang tinggi. Dana investasi tersebut akan diinvestasikan kepada perusahaan-perusahaan yang memiliki reputasi dengan nilai perusahaan yang baik, yang juga memiliki kemampuan untuk memperoleh laba. Laba yang tinggi akan membuat perusahaan meningkatkan pembagian dividennya kepada para pemegang saham, sehingga harapan bagi kemakmuran para pemegang saham dapat terpenuhi (Harjito \& Martono 2013, hlm.3).

Tetapi, untuk mendapatkan nilai perusahaan yang baik membuat sering munculnya konflik antara pengelola perusahaan (manajer) dengan para pemegang saham sebagai pemilik. 
Tidak jarang manajer perusahaan memiliki tujuan lain yang mungkin bertentangan dengan tujuan utama dari perusahaan tersebut. Perbedaan kepentingan ini yang disebut sebagai masalah keagenan atau agency problem (Harjito \& Martono 2013, hlm. 12).

Kasus di PT Semen Baturaja Tbk (SMBR) yang mengalami penurunan pada penjualan bersih sebesar $0,36 \%$ yaitu menjadi $\mathrm{Rp} 502,43$ miliar dibandingkan dengan periode sama tahun sebelumnya yang tercatat sebesar Rp 504,27 miliar. Meskipun penjualan bersih mengalami penurunan, tetapi PT Semen Baturaja Tbk (SMBR) meraih peningkatan laba bersih sebesar $0,76 \%$ dengan nominal $\mathrm{Rp} 123,14$ miliar dibandingkan dengan semester yang sama tahun sebelumnya yang bernilai Rp 122,21 miliar dikarenakan PT Semen Baturaja Tbk (SMBR) melakukan peningkatan efisiensi yang menyebabkan beban usaha turun menjadi Rp 56,03 miliar dari sebelumnya sebesar Rp 57,12 miliar. Tetapi pada perdagangan saham hari Rabu (23/7/14), saham SMBR dibuka pada $\mathrm{Rp} 420$ dan ditutup di lever $\mathrm{Rp}$ 409 dengan volume transaksi sebanyak 14,6 juta lembar yang menunjukkan bahwa saham melemah. (Allens, 2014)

Peningkatan laba bersih yang didapat seharusnya dapat berdampak pada peningkatkan harga saham karena para investor tertarik untuk menanamkan modalnya pada perusahaan tersebut sehingga membuat nilai perusahaan ikut meningkat.

Penelitian ini merujuk pada penelitian yang dilakukan oleh Rizqia dkk (2013) mengenai Effect of Managerial Ownership, Financial Leverage, Profitability, Firm Size, and
Investment Opportunity on Dividend Policy and Firm Value. Perbedaan penelitian ini dengan penelitian yang dilakukan oleh Rizqia dkk (2013) adalah peneliti mengubah proksi pada pengukuran profitabilitas dengan menggunakan Return On Equity (ROE), perbedaan lainnnya adalah peneliti menggunakan periode tahun yang lebih baru yaitu periode tahun 2013-2014.

Tujuan penelitian ini adalah untuk menganalisis pengaruh profitabilitas, leverage dan ukuran perusahaan terhadap nilai perusahaan pada perusahaan industri dasar dan kimia yang terdaftar di BEI selama periode 2013-2014. Hasil penelitian ini diharapkan dapat dijadikan informasi oleh perusahaan sebagai dasar bagi para manajemen dalam mengambil keputusan dalam meningkatkan kemakmuran para pemegang saham dan juga dapat dijadikan pertimbangan bagi para pemegang saham untuk menginvestasikan dana yang dimilikinya serta bagi para akademisi untuk dijadikan acuan dalam melakukan penelitian yang lebih baik di masa yang akan datang mengenai nilai perusahaan.

\section{Perumusan Masalah}

a. Apakah Profitabilitas berpengaruh secara parsial terhadap Nilai Perusahaan?

b. Apakah Leverage berpengaruh secara parsial terhadap Nilai Perusahaan?

c. Apakah Ukuran Perusahaan berpengaruh secara parsial terhadap Nilai Perusahaan? 


\section{TINJAUAN PUSTAKA DAN PENGEMBANGAN HIPOTESIS \\ Teori Sinyal (Signalling Theory)}

Menurut Brigham \& Houston (2011, hlm.184) menyatakan bahwa, 'setiap orang, baik investor maupun manajer memiliki informasi yang sama tentang prospek suatu perusahaan. Hal ini disebut sebagai informasi simetris (Symmetric information)'. Menurut Suwardjono (2010, hlm.490) menyatakan bahwa, 'laba akuntansi yang diumumkan via statmen keuangan merupakan salah satu signal dari himpunan informasi yang tersedia bagi pasar modal'.

Menurut Brigham \& Houston (1999, hlm.36) dalam Moniaga (2013) menyatakan bahwa, 'isyarat atau signal merupakan suatu tindakan yang diambil manajemen perusahaan yang memberi petunjuk bagi investor tentang bagaimana manajemen memandang prospek perusahaan'.

Dalam mencapai tujuan perusahaan tidak jarang akan muncul berbagai perbedaan pendapat antara para pemegang saham dengan para manajer. Perbedaan tersebut disebut masalah keagenan (Agency Problem) yang dapat terjadi karena manajer mengutamakan kepentingan pribadi, tetapi sebaliknya para pemegang saham tidak menyukai kepentingan pribadi dari manajer karena apa yang dilakukan oleh manajer tersebut dapat menambah biaya yang akan dikeluarkan oleh perusahaan sehingga dapat menyebabkan penurunan keuntungan perusahaan sehingga dividen yang akan diterima oleh para pemegang saham juga akan mengalami penurunan. Perbedaan kepentingan ini biasanya timbul karena pihak manajemen tidak memiliki saham dimana tempat mereka bekerja, sehingga para manajer tidak lagi berusaha untuk memaksimumkan laba perusahaan dan cenderung akan mengambil keuntungan dari beban perusahaan seperti meningkatkan kekayaan pribadi, meningkatkan fasilitas perusahaan atau mengadakan acara kantor, yang akan menurunkan laba perusahaan karena meningkatnya beban yang dikeluarkan oleh perusahaan atas aktivitas tersebut. Sedangkan para pemegang saham mengharapkan perusahaan dapat meminimalkan beban yang dikeluarkan oleh perusahaan sehingga laba yang didapatkan akan lebih tinggi, karena laba yang tinggi akan meningkatkan tingkat kemakmuran bagi para pemegang saham.

Dan pada keadaan yang dialami oleh perusahaan baik perusahaan sedang mengalami kenaiakan laba atau mengalami penurunan laba maka pihak manajer diharapkan dapat memberikan informasi yang sama mengenai keadaan perusahaan kepada semua pihak, hal ini disebut dengan teori sinyal (Signalling Theory). Tindakan manajer dalam memberikan informasi yang sama kepada semua pihak bertujuan agar para investor yang telah menanamkan atau akan menanamkan sahamnya kepada suatu perusahaan dapat melihat prospek perusahaan dan dapat digunakan untuk mempertimbangkan dalam mengambil keputusan mengenai modal investasinya.

\section{Nilai Perusahaan}

Suatu perusahaan didirikan untuk mencapai tujuan-tujuan tertentu dengan menetapkan strategi untuk mencapainya. Salah satu tujuan 
perusahaan adalah untuk memaksimalkan nilai perusahaan.

Menurut Brealey \& Myers (2007, hlm. 46) menyatakan bahwa, nilai perusahaan mengikhtisarkan penilaian kolektif investor tentang seberapa baik keadaan suatu perusahaan, baik kinerja saat ini maupun prospek masa depannya.

Menurut Silveira \& Barros dalam Nuraina (2012) menyatakan bahwa, nilai perusahaan sebagai apresiasi atau penghargaan investor terhadap sebuah perusahaan. Nilai tersebut tercermin pada harga saham perusahaan.

Menurut Fakhruddin \& Hadianto dalam Moniaga (2013) menyatakan bahwa nilai perusahaan merupakan persepsi investor terhadap perusahaan, yang sering dikaitkan dengan harga saham. Harga saham yang tinggi membuat nilai perusahaan juga tinggi. Harga saham merupakan harga yang terjadi pada saat saham diperdagangkan dipasar.

Menurut Fama (1978) dalam Dewi (2013) menyatakan bahwa nilai perusahaan dapat dilihat dari harga sahamnya. Harga saham terbentuk atas permintaan dan penawaran investor, sehingga saham tersebut dapat dijadikan proksi nilai perusahaan.

Nilai perusahaan diukur dengan menggunakan Price Book Value (PBV). Rasio ini mengukur nilai yang diberikan pasar keuangan kepada manajemen dan organisasi perusahaan sebuah perusahaan yang terus tumbuh. Nilai buku (book value) dihitung dengan cara total ekuitas dibagi jumlah saham yang beredar. Untuk mencari market value yaitu dengan menghitung rata-rata harga saham sampai hari kelima setelah tanggal publikasi.

\section{Profitabilitas}

Suatu perusahaan pasti bertujuan untuk memperoleh laba atau keuntungan yang sebanyak-banyaknya. Dengan tingginya tingkat keuntungan atau laba suatu perusahaan maka akan meningkat pula kemakmuran para pemegang saham sebagai pemilik perusahaan. Maka dari itu, pastilah perusahaan akan memaksimalkan kinerja para karyawan dan manajemen juga akan dituntut untuk dapat mecapai target yang sudah ditentukan agar bisa mendapatkan laba semaksimal mungkin.

Menurut Nurhayati, (2013) menyatakan bahwa, profitabilitas adalah tingkat keuntungan bersih yang mampu diraih oleh perusahaan pada saat menjalankan operasinya. Semakin besar keuntungan yang diperoleh, semakin besar kemampuan perusahaan untuk membayar dividennya.

Rasio profitabilitas (Sjahrial 2013, hlm. 40), merupakan pengukuran kemampuan dalam memperoleh laba dengan menggunakan aset atau modal perusahaan. Dapat dipastikan bahwa semakin tinggi rasio ini adalah semakin baik karena laba yang diperoleh semakin besar. Rasio profitabilitas (Harahap 2011, hlm. 304), menggambarkan kemampuan perusahaan mendapatkan laba melalui semua kemampuan dan sumber yang ada seperti kegiatan penjualan, kas, modal, jumlah karyawan, jumlah cabang dan sebagainya. Menurut ( Kasmir 2014, hal 196), Rasio profitabilitas merupakan rasio untuk menilai kemampuan perusahaan dalam mencari keuntungan.rasio ini juga memberikan ukuran tingkat efektivitas manajemen suatu perusahaan. 
Profitabilitas diukur dengan menggunakan Return On Equity (ROE). Rasio ini mengukur laba bersih sesudah pajak dengan modal sendiri.

\section{Leverage}

Suatu perusahaan pastilah memerlukan dana untuk dapat menjalankan usahanya, dana tersebut dapat berasal dari modal sendiri ataupun dari sumber lainnya. Salah satu sumber dana bagi suatu perusahaan adalah dari pinjaman atau utang. Utang yang digunakan oleh perusahaan juga harus disesuaikan dengan kebutuhan perusahaan agar dapat mencapai tujuan yang sudah ditentukan.

Menurut Sitanggang (2014, hlm. 23) menyatakan bahwa rasio utang (leverage) merupakan ukuran seberapa besar perusahaan dibiayai oleh unsur utang dan seberapa besar kemampuan perusahaan dari hasil operasi perusahaan untuk melunasi beban pembayaran bunga dan atau pokok pinjaman tersebut.

Rasio solvabilitas atau leverage ratio merupakan rasio yang digunakan untuk mengukur sejauh mana aktiva perusahaan dibiayai dengan utang. (Kasmir 2014, hlm. 151). Menurut Harahap (2011, hlm. 306) menyatakan bahwa rasio leverage menggambarkan hubungan antara hutang perusahaan terhadap modal maupun asset. Rasio ini dapat melihat seberapa jauh perusahaan dibiayai oleh utang atau pihak luar dengan kemampuan perusahaan yang digambarkan oleh modal (equity). Perusahaan yang baik mestinya memiliki komposisi modal yang lebih besar dari utang.

Leverage diukur dengan menggunakan proksi Debt to Asset
Ratio (DAR). Rasio ini mengukur perbandingan antara total utang dengan total aktiva. Dengan kata lain, seberapa besar aktiva perusahaan dibiayai oleh hutang atau seberapa besar utang perusahaan berpengaruh terhadap pengelolaan aktiva.

\section{Ukuran Perusahaan}

Suatu perusahaan pastinya ingin memiliki ukuran perusahaan yang besar. Ukuran perusahaan ini lah yang akan menjadi nilai yang digunakan untuk menunjukkan besar atau kecilnya suatu perusahaan.Menurut Sujianto dalam Nuraina (2012) menyatakan bahwa ukuran perusahaan menggambarkan besar kecilnya suatu perusahaan yang ditunjukkan oleh total aktiva, jumlah penjualan, rata-rata total penjualan dan rata-rata total aktiva. Jadi, ukuran perusahaan merupakan ukuran atau besarnya aset yang dimiliki oleh suatu perusahaan.

Sitanggang (2013, hlm. 76) menyatakan bahwa, ukuran perusahaan dengan kapasitas pasar atau penjualan yang besar menunjukan prestasi perusahaan.

Menurut Analisa (2011) dalam Dewi (2013) menyatakan bahwa ukuran perusahaan mempunyai pengaruh yang berbeda terhadap nilai perusahaan suatu perusahaan. Dalam hal ukuran perusahaan dilihat dari total assets yang dimiliki oleh perusahaan, yang dapat dipergunakan untuk kegiatan operasi perusahaan.

\section{Pengembangan Hipotesis}

Pengaruh Profitabilitas terhadap Nilai Perusahaan

Menurut Sjahrial (2013, hlm.40) yang menyatakan bahwa, 'rasio 
profitabilitas merupakan pengukuran kemampuan perusahaan dalam memperoleh laba dengan menggunakan aset atau modal perusahaan. Maka dapat dipastikan bahwa semakin tinggi rasio ini adalah semakin baik karena laba yang akan diperoleh juga akan semakin besar, sehingga kemakmuran para pemegang saham melalui pembagian dividen juga akan tecapai'. Teori sinyal yang merupakan tindakan manajemen dari suatu perusahaan untuk memberikan informasi yang sama terhadap investor memiliki hubungan dengan profitabilitas yaitu tentang bagaimana manajemen memberikan informasi yang sama kepada para investor mengenai tingkat keuntungan atau laba yang diperoleh oleh perusahaan sehingga para pemegang saham dapat mengetahui tentang prospek kedepannya mengenai perusahaan yang ditanamkan modalnya. Hasil penelitian sebelumnya yang sudah terbukti bahwa profitabilitas memiliki pengaruh terhadap nilai perusahaan dan sejalan dengan teori profitabilitas adalah penelitian yang dilakukan oleh $\mathrm{Li} \&$ Shun (2011), Mahendra, dkk (2012), Dewi \& Wirajaya (2013), Rizqia, dkk (2013), dan Nurhayati (2013). Penelitian tersebut menemukan hasil bahwa profitabilitas memiliki pengaruh signifikan positif terhadap nilai perusahaan. Profitabilitas merupakan tingkat keuntungan bersih yang mampu diraih oleh perusahaan pada saat menjalankan kegiatan operasinya. Semakin besar keuntungan yang diperoleh oleh perusahaan, maka akan semakin besar kemampuan perusahaan untuk membayar dividennya, sehingga nilai perusahaan akan meningkat.
Berdasarkan uraian diatas, maka hipotesis penelitian pertama yang dapat dikembangkan adalah:

$\mathrm{H}_{1}$ : Profitabilitas berpengaruh secara parsial terhadap Nilai Perusahaan.

\section{Pengaruh Leverage Terhadap Nilai Perusahaan}

Menurut Harahap (2011, hlm.306) yang menyatakan bahwa, 'rasio leverage menggambarkan hubungan antara hutang perusahaan terhadap modal maupun aset. Rasio ini dapat melihat seberapa jauh perusahaan dibiayai oleh utang atau pihak luar dengan kemampuan perusahaan yang digambarkan oleh modal (equity). Perusahaan yang baik mestinya memiliki komposisi modal yang lebih besar dari utangnya'. Teori agensi yang di dalamnya terdapat masalah mengenai perbedaan kepentingan antara manajemen perusahaan dengan para pemegang saham sebagai pemilik perusahaan, dimana manajer sering sekali membuat keputusan-keputusan yang tidak sejalan dengan kemauan para pemegang saham, memiliki hubungan dengan leverage yaitu dimana pihak manajemen perusahaan ingin medapatkan dana sebanyak-banyaknya untuk menjalankan kegiatan perusahaan salah satunya melalui utang, sedangkan para pemilik perusahaan tidak menyukai keputusan manajemen untuk memperoleh banyak dana melalui utang dikarenakan tingkat utang yang tinggi akan berpengaruh terhadap laba sehingga nilai perusahaan akan turun dan kemakmuran para pemegang saham juga ikut menurun. Hasil penelitian sebelumnya yang sudah terbukti bahwa leverage memiliki pengaruh terhadap 
nilai perusahaan dan sejalan dengan teori leverage adalah penelitian yang dilakukan oleh Sujoko \& Soebiantoro (2007), Rizqia, dkk (2013). Penelitian tersebut menemukan hasil bahwa leverage memiliki pengaruh signifikan negatif terhadap nilai perusahaan. Jumlah utang yang meningkat untuk mendanai kegiatan operasa perusahaan akan menyebabkan penurunan pendapatan perusahaan sehingga dapat menurunkan nilai perusahaan.

Berdasarkan uraian diatas, maka hipotesis penelitian kedua yang dapat dikembangkan adalah:

$\mathrm{H}_{2}$ : Leverage berpengaruh secara parsial terhadap Nilai Perusahaan.

\section{Pengaruh Ukuran Perusahaan Terhadap Nilai Perusahaan}

Menurut Sitanggang (2013, hlm.76) yang menyatakan bahwa, 'ukuran perusahaan dengan kapasitas pasar atau penjualan yang besar dapat menunjukan prestasi dari suatu perusahaan. Besar atau kecilnya ukuran perusahaan dapat di lihat dati total aktiva atau total penjualan suatu perusahaan'.

Teori sinyal merupakan tindakan manajemen suatu perusahaan untuk memberikan informasi yang sama terhadap para investor. Teori sinyal memiliki hubungan dengan ukuran perusahaan yaitu dimana manajemen harus memberi tahukan informasi yang sama mengenai ukuran perusahaan melalui total aset atau total penjualan yang dimiliki oleh perusahaan kepada para pemegang saham. Sehingga para pemegang saham dapat mengetahui seberapa besar ukuran perusahaan yang mereka tanamkan modalnya, dan agar para investor dapat mengetahui prospek perusahaan tersebut ke depannya dalam keadaan baik atau buruk.

Hasil penelitian sebelumnya yang sudah terbukti bahwa ukuran perusahaan memiliki pengaruh terhadap nilai perusahaan dan sejalan dengan teori ukuran perusahaan adalah penelitian yang dilakukan oleh Nuraina (2012), Rizqia, dkk (2013), dan Nurhayati (2013). Penelitian tersebut menemukan hasil bahwa ukuran perusahaan memiliki pengaruh signifikan positif terhadap nilai perusahaan. Suatu perusahaan besar akan lebih mudah dalam mengakses masuk ke pasar modal, sehingga akan mudah mendapatkan investor sehingga nilai perusahaan akan meningkat melalui harga sahamnya.

Berdasarkan uraian diatas, maka hipotesis penelitian ketiga yang dapat dikembangkan adalah:

$\mathrm{H}_{3}$ : Ukuran Perusahaan berpengaruh secara parsial terhadap Nilai Perusahaan (Firm Value). 
Kerangka Penelitian

Berdasarkan dari penjelasan sebelumnya, maka dapat digambarkan melalui kerangka pemikiran sebagai berikut:

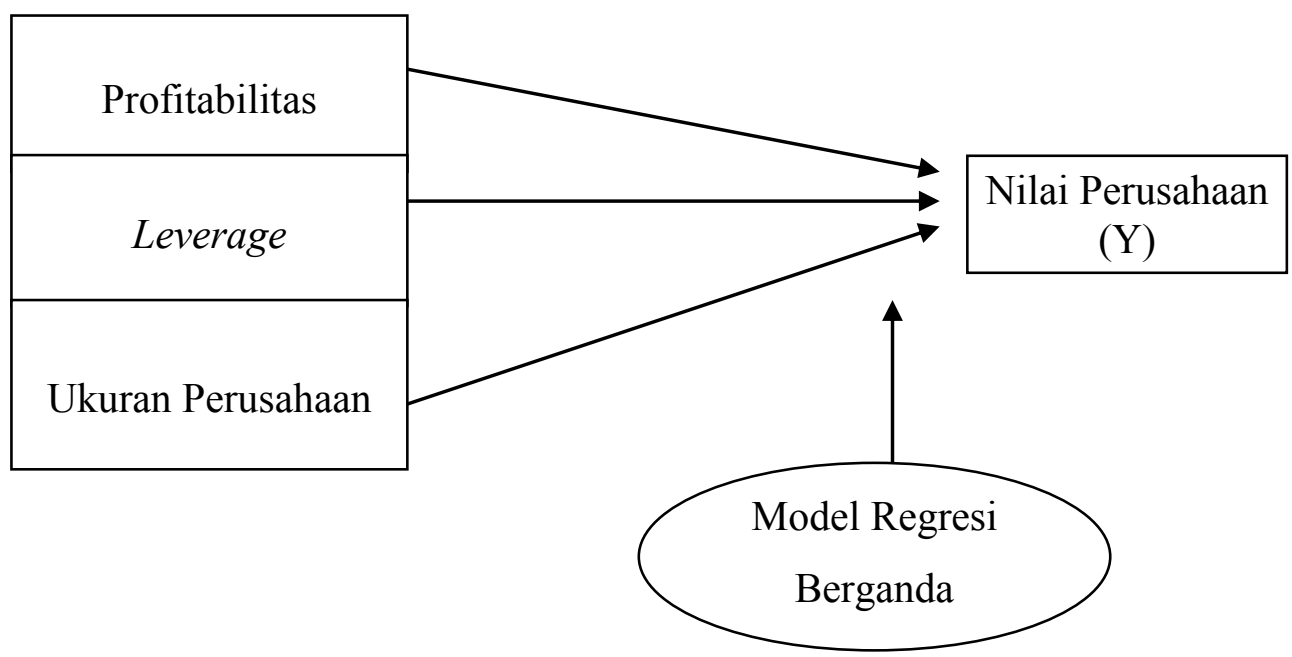

\section{Gambar 1 Diagram Kerangka Penelitian}

\section{METODE PENELITIAN}

Sumber data yang digunakan merupakan data sekunder yaitu laporan keuangan yang dipublikasikan yang diperoleh dari Bursa Efek Indonesia (BEI) berupa laporan keuangan tahunan perusahaan dan bahan kajian lain yang diperoleh dari buku, jurnal, situs resmi duni investasi dan artikel. Jenis data yang digunakan adalah data kuantitatif.

\section{SAMPEL}

Populasi dalam penelitian ini adalah seluruh perusahaan manufaktur sektor industri dasar dan kimia yang terdaftar di Bursa Efek Indonesia (BEI) tahun 2013-2014. Teknik penentuan sampel dalam penelitian ini menggunakan purposive sampling dengan kriteria sebagai berikut:

a. Perusahaan manufaktur sektor industri dasar dan kimia yang listing di Bursa Efek Indonesia (BEI) dengan periode selama tahun 2013 -2014

b. Perusahaan manufaktur sektor industri dasar dan kimia yang memiliki data laporan keuangan yang lengkap terkait variabelvariabel

c. Perusahaan manufaktur sektor industri dasar dan kimia yang memiliki laba

d. Perusahaan manufaktur sektor industri dasar dan kimia yang menggunakan satuan mata uang rupiah dalam laporan keuangannya.

\section{Pengukuran Variabel}

Variabel dependen dalam penelitian ini adalah Nilai perusahaan yang diukur menggunakan Price Book Value (PBV) yang membandingkan harga pasar saham dengan nilai buku 
saham. Berikut rumus Price Book Value adalah sebagai berikut:

$$
\mathrm{PBV}=\frac{\text { Harga Pasar per Lembar Saham }}{\text { Nilai Buku per Lembar Saham }}
$$

Dimana harga pasar per lembar saham diperoleh melalui perhitungan rata-rata harga saham 5 hari setelah tanggal publikasi laporan keuangan. Dan nilai buku per lembar saham dapat diperoleh melalui perhitungan:

Nilai Buku per

Lembar Saham

$$
=\frac{\text { Total Ekuitas }}{\text { Jumlah Saham beredar }}
$$

Variabel independen dalam penelitian ini adalah:

1) Profitabilitas $\left(X_{1}\right)$

Profitabilitas diukur dengan menggunakan skala data rasio melalui total laba bersih dengan ekuitas perusahaan. Berikut rumus Return On Equity:

$\begin{gathered}\text { Return on } \\ \text { Equity } \\ \text { (ROE) }\end{gathered}$
Leverage

2) Leverage $\left(\mathrm{X}_{2}\right)$

Leverage diukur dengan menggunakan skala data rasio melalui total utang dengan total aktiva perusahaan. Berikut rumus Debt to Asset Ratio:

Debt to asset

$$
=\frac{\text { Total debt }}{\text { Total assets }}
$$

3) Ukuran Perusahaan $\left(X_{3}\right)$

Ukuran perusahaan diukur dengan skala data rasio melalui log natural of total aktiva. Digunakan untuk mengurangi perbedaan yang signifikan antara ukuran perusahaan yang terlalu besar, maka nilai total asset dibentuk menjadi logaritma natural, kovensi ke bentuk logaritma natural ini bertujuan untuk membuat data total aktiva terdistribusi normal.

$$
\text { Firm Size }=\text { Ln Total Assets }
$$

\section{HASIL DAN PEMBAHASAN}

Data yang digunakan pada penelitian ini diambil berdasarkan laporan keuangan yang telah dipublikasikan oleh Bursa Efek Indonesia periode tahun 2013 sampai dengan tahun 2014. Laporan keuangan yang digunakan pada penelitian ini diantara lain adalah laporan posisi keuangan, laporan laba rugi, serta data harga pasar saham setelah diterbitkannya laporan keuangan oleh Bursa Efek Indonesia (BEI). Di dalam penelitian ini, variabel dependen (dependent) adalah Nilai Perusahaan yang diproksikan dengan Price to Book Value (PBV), sedangkan variabel independennya (independent) adalah Profitabilitas yang diproksikan dengan Return on Equity (ROE), Leverage yang diproksikan dengan Debt to Assets Ratio (DAR), dan Ukuran Perusahaan yang diproksikan dengan Ln Total Assets. Sebelum melakukan analisis statistik deskriptif dan analisis uji hipotesis, data penelitian yang telah terkumpul untuk penelitian ini akan diidentifikasi terlebih dahulu, apakah setiap variabel terdistribusi secara normal atau tidak. Jika telah memenuhi uji normalitas, maka residual akan terdistribusi secara normal dan independen. Tetapi, pada penelitian ini data nilai perusahaan yang diolah tidak terdistribusi secara normal. Maka dilakukan outlier data 
dengan melihat data yang memiliki karakteristik unik yang terlihat sangat berbeda jauh dari sampel lainnya. Berdasarkan dari hasil outlier data terdapat beberapa data yang tidak dapat terdistribusi secara normal sehingga tidak dapat dijadikan sampel data penelitian. Dari 52 sampel yang ada, maka diperoleh jumlah sampel (n) sebanyak 48 sampel atau 24 perusahaan yang digunakan dalam penelitian ini untuk periode tahun 2013 sampai dengan tahun 2014 (2 tahun).

\section{Analisis Deskriptif}

Penelitian ini menggunakan teknik analisis statistik deskriptif. Dimana statistik deskriptif akan memberikan gambaran atau deskripsi suatu data yang dilihat dari nilai ratarata (mean), standar deviasi, varian, maksimum, minimum, sum, range, kurtosis, dan skewness. Berdasarkan dari hasil pengolahan data yang dilakukan dengan menggunakan IBM SPSS Statistic 20, maka diperoleh hasil perhitungan statistik sebagai berikut:

Tabel 1 Statistik Deskriptif

Descriptive Statistics

\begin{tabular}{lccccc}
\hline & $\mathrm{N}$ & Minimum & Maximum & Mean & $\begin{array}{c}\text { Std. } \\
\text { Deviation }\end{array}$ \\
\hline Profitabilitas & 48 & .0030 & .2990 & .109152 & .0741568 \\
Leverage & 48 & .0715 & .8375 & .358924 & .2271759 \\
Ukuran Perusahaan & 48 & 25.6370 & 31.1666 & 27.903509 & 1.6396621 \\
Nilai Perusahaan & 48 & .1349 & 4.1023 & 1.269838 & 1.0225787 \\
Valid N (listwise) & 48 & & & & \\
\hline \multicolumn{2}{l}{ Sumber: Data sekunder yang telah diolah }
\end{tabular}

Sumber: Data sekunder yang telah diolah

Berdasarkan dari hasil statistik deskriptif tabel 1 diatas, maka dapat diketahui bahwa Nilai Perusahaan yang diukur dengan Price to Book Value (PBV), memiliki nilai rata-rata sebesar 1.2698 atau $126.98 \%$ dengan jumlah data (n) sebanyak 48, hal ini menunjukkan bahwa rata-rata harga saham pada perusahaan sektor industri dasar dan kimia sebesar $126.98 \%$ dari nilai bukunya. Nilai maksimum sebesar 4.1023 atau $410.23 \%$ yang berasal dari PT. Semen Indonesia (Persero), Tbk (SMGR) pada tahun 2013. Nilai minimum sebesar 0.1349 atau $13.49 \%$ yang berasal dari PT. Alumindo Light Metal Industry, Tbk (ALMI) pada tahun 2013.
Profitabilitas yang diukur dengan Return on Equity (ROE), memiliki nilai rata-rata sebesar 0.10915 atau $10.915 \%$, hal ini menunjukan bahwa rata-rata laba yang diperoleh oleh perusahaan sektor industri dasar dan kimia adalah sebesar $10.915 \%$ dari total ekuitas perusahaan. Nilai minimum sebesar 0.003 atau $0.3 \%$ berasal dari PT. Alumindo Light Metal Industry, Tbk (ALMI) pada tahun 2014 hal ini menunjukan bahwa laba yang mampu diperoleh oleh perusahaan ini sangat kecil bila dibandingkan dengan ekuitas yang dimiliki oleh perusahaan. Nilai maksimum sebesar 0.299 atau 29.9\% berasal PT. Duta Pertiwi Nusantara, Tbk (DPNS) pada tahun 2013, hal ini menunjukan bahwa 
kemampuan perusahaan dalam memperoleh laba sebesar $29.9 \%$ dari modal sendiri yang dimiliki oleh perusahaan tersebut.

Leverage yang diukur dengan Debt to Assets Ratio (DAR), memiliki nilai rata-rata sebesar 0.3589 atau $35.89 \%$ ini menunjukkan bahwa setiap perusahaan sektor industri dasar dan kimia rata-rata memperoleh dana dari pihak eksternal atau hutang sebesar $35.89 \%$ dari total asetnya. Nilai maksimum sebesar 0.8375 atau $83.75 \%$ berasal dari PT. Indal Alumunium Industry, Tbk (INAI) pada tahun 2014, hal ini menunjukkan bahwa perusahaan sangat bergantung pada hutang sebagai sumber dana dalam menjalankan kegiatan operasinya. Kondisi ini sangat tidak baik, karena akan meningkatkan tingkat risiko atas pendapatan perusahaan, dimana penggunaan hutang disini akan menimbulkan kemungkinan terjadinya perusahaan tidak mampu membayar kewajiban pokok dan juga kewajiban bunga pinjaman sehingga risiko kebangkrutan akan semakin tinggi. Nilai minimum sebesar 0.0715 atau $7.15 \%$ yang berasal dari PT. Semen Baturaja (Persero), Tbk (SMBR) pada tahun 2014, hal ini dapat dikatakan baik karena perusahaan tidak bergantung pada hutang sebagai sumber dana dalam menjalankan kegiatan operasinya, namun di lain sisi hal ini juga bisa dikatakan kurang baik karena perusahaan bisa dianggap bahwa perusahaan tidak mendapatkan kepercayaan dari pihak eksternal dikarenakan persentase hutang yang kecil.

Ukuran Perusahaan manufaktur sektor industri dasar dan kimia yang diproksikan dengan Ln Total Asset, memiliki nilai rata-rata sebesar 27.9035. Nilai minimum sebesar 25.637 dengan total aset $\mathrm{Rp}$ 136.142.063.219 yang berasa dari PT. Intanwijaya International Tbk (INCI) pada tahun 2013, hal ini menunjukan bahwa ukuran perusahaan perusahaan ini paling kecil di antara sampel perusahaan manufaktur sektor industri dasar dan kimia lainnya. Nilai maksimum sebesar 31.166 dengan total aset $\mathrm{Rp}$ 34.314.666.027.000 yang berasal dari PT. Semen Indonesia (Persero) Tbk (SMGR) pada tahun 2014, hal tersebut dapat disimpulkan bahwa perusahaan tersebut memiliki ukuran perusahaan yang sangat besar di antara sampel yang lainnya, dimana perusahaan tersebut memiliki aktiva yang sangat besar yang dapat dipergunakan sebagai sumber daya untuk melaksanakan kegiatan operasi dan invetasi perusahaan.

\section{Analisis Asumsi Klasik terdiri dari Uji Normalitas}

Uji normalitas bertujuan untuk menguji apakah dalam model regresi, variabel pengganggu atau residual memiliki distribusi yang normal. Uji normalitas dapat normal probability plot.

\section{Gambar 2 Hasil Pengujian Normalitas dengan P-Plot}

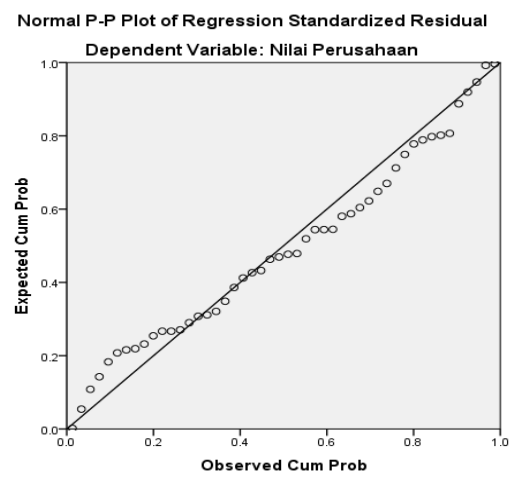

Sumber: Data sekunder yang telah diolah 
Dari hasil diatas dapat dilihat bahwa hasil data sampel dalam penelitian ini menyebar mengikuti garis diagonal, maka model regresi ini memenuhi asumsi normalitas.

\section{Uji Multikolinearitas}

Uji multikolinearitas bertujuan untuk menguji apakah model regresi ditemukan adanya korelasi antar variabel bebas (independen). Model regresi yang baik seharusnya tidak terjadi korelasi di antara variabel independen. Untuk mendeteksinya dapat dilakukan dengan melihat tolerance value dan variance inflation factor (VIF). Jika nilai Tolerance > 0,10 dan VIF $<10$ maka tidak terjadi multikolinearitas.

Tabel 2 Hasil Uji Multikolinearitas

Coefficients $^{a}$

\begin{tabular}{|c|c|c|c|}
\hline \multirow[t]{2}{*}{ Model } & & \multicolumn{2}{|c|}{ Collinearity Statistics } \\
\hline & & Tolerance & $V I F$ \\
\hline \multirow[t]{4}{*}{1} & (Constant) & & \\
\hline & Profitabilitas & .869 & 1.150 \\
\hline & Leverage & .847 & 1.181 \\
\hline & Ukuran Perusahaan & .908 & 1.101 \\
\hline
\end{tabular}

a. Dependent Variable: Nilai Perusahaan

Sumber: Data sekunder yang telah diolah

Berdasarkan hasil diatas, maka dapat diketahui bahwa nilai Variance Inflation Factor (VIF) dari variabel profitabilitas sebesar 1.150 , leverage sebesar 1.181 dan ukuran perusahaan sebesar 1.101, hal ini menunjukan bahwa masing-masing variabel independen memiliki nilai VIF yang lebih kecil dari 10 atau VIF $<10$ dan nilai Tolerance variabel profitabilitas sebesar 0.869 , leverage sebesar 0.847 dan ukuran perusahaan sebesar 0.908 , hal ini berarti bahwa nilai Tolerance lebih besar dari 0,10 atau nilai tolerance $>0,10$. Hal ini menunjukkan bahwa model regresi dalam penelitian ini tidak terjadi multikolinearitas.

\section{Uji Autokorelasi}

Uji autokorelasi bertujuan menguji apakah dalam model regresi linear ada korelasi antara kesalahan pengganggu pada periode $t$ dengan kesalahan pengganggu pada periode $\mathrm{t}-1$ (sebelumnya). Jika terjadi korelasi, maka dinamakan ada problem autokorelasi. Uji autokorelasi dapat dilakukan dengan menggunakan Uji Durbin-Watson (DW Test).

\section{Tabel 3 Hasil Autokorelasi}

Model Summary ${ }^{b}$

\begin{tabular}{cc}
\hline Model & Durbin-Watson \\
\hline 1 & 2.016 \\
\hline a. Predictors: (Constant), Ukuran Perusho
\end{tabular}

a. Predictors: (Constant), Ukuran Perusahaan, Profitabilitas,

Leverage

b. Dependent Variable: Nilai Perusahaan

Sumber: Data sekunder yang telah diolah 
Berdasarkan hasil uji autokorelasi diatas, maka dapat terlihat bahwa nilai Durbin-Watson sebesar 2,016. Menurut tabel 3 pengambilan keputusan autokorelasi, model regresi linear dikatakan tidak terdapat autokorelasi jika nilai $\mathrm{du}<\mathrm{d}<4$-du. Sehingga didapat

\section{Uji Hipotesis}

\section{Uji F dan $\mathbf{R}^{2}$}

a. Uji F (Uji Simultan)

Uji statistik $F$ pada dasarnya menunjukkan apakah semua variabel independen yang dimasukkan ke dalam model mempunyai pengaruh secara bersama-sama (simultan) bahwa 1,6708 $<2,016<2.3292$, maka dapat disimpulkan bahwa pada model regresi ini tidak terdapat masalah autokorelasi. Untuk melihat tabel Durbin-Watson, dapat dilihat pada lampiran.

terhadap variabel dependen atau tidak. Uji $\mathrm{F}$ dapat diuji berdasarkan nilai signifikansi, apakah variabel profitabilitas, leverage, dan ukuran perusahaan secara simultan memiliki pengaruh yang signifikan atau tidak dengan variabel Nilai Perusahaan.

Tabel 4 Hasil Uji F (Simultan)

\begin{tabular}{lcccccc}
\multicolumn{8}{c}{ ANOVA $^{\mathbf{a}}$} \\
\hline Model & Sum of Squares & Df & Mean Square & $F$ & Sig. \\
\hline 1 & Regression & 34.514 & 3 & 11.505 & 34.596 & $.000^{\mathrm{b}}$ \\
& Residual & 14.632 & 44 & .333 & & \\
& Total & 49.146 & 47 & & & \\
\hline
\end{tabular}

a. Dependent Variable: Nilai Perusahaan

b. Predictors: (Constant), Ukuran Perusahaan, Profitabilitas, Leverage

Sumber: Data sekunder yang telah diolah

Pada tabel 4 uji F (uji simultan) dapat dilihat bahwa terdapat tingkat signifikansi sebesar 0.000 dengan nilai $F_{\text {hitung }}$ sebesar 34.596. Sedangkan nilai $\mathrm{F}_{\text {tabel }}$ dengan jumlah sampel $(\mathrm{n})=$ 48 , jumlah variabel $(\mathrm{k})=4$ maka $\mathrm{df}_{1}$ atau df pembilang $=(\mathrm{k}-1)=(4-1)=$ 3 , maka $\mathrm{df}_{1}=3$. Sedangkan $\mathrm{df}_{2}$ atau df penyebut $=(\mathrm{n}-\mathrm{k}-1)=(48-3-1)=$ 44 , maka $\mathrm{df}_{2}=44$. Dengan melihat tabel distribusi $\mathrm{F}$ maka diperoleh $\mathrm{F}_{\text {tabel }}$ $2.82<\mathrm{F}_{\text {hitung }} 34.596$ dengan tingkat signifikansi sebesar $0,000<0,05$. Dengan demikian, maka dapat disimpulkan bahwa profitabilitas, leverage, dan ukuran perusahaan secara simultan (bersama-sama) memiliki pengaruh yang signifikan terhadap nilai perusahaan.

b. Uji $\mathrm{R}^{2}$ (Uji Koefisien Determinasi)

Koefisien determinasi $\left(\mathrm{R}^{2}\right)$ bertujuan untuk mengukur seberapa jauh kemampuan model dalam menerangkan variasi variabel dependen. Nilai koefisien determinasi adalah antara nol dan satu. Dalam penelitian ini, digunakan nilai Adjusted $\mathrm{R}^{2}$, nilai $\mathrm{R}^{2}$ yang kecil berarti menunjukan bahwa kemampuan variabel-variabel independen dalam menjelaskan variasi variabel dependen amat terbatas. Nilai yang mendekati satu berarti variabel-variabel independen memberikan hampir semua informasi 
yang dibutuhkan untuk memprediksi variasi variabel dependen.

Maka Uji $\mathrm{R}^{2}$ (Uji Koefisien Determinasi) dilakukan untuk mengukur seberapa besar variabel independen (Profitabilitas, Leverage, dan Ukuran Perusahaan) dapat mempengaruhi perubahan yang terjadi pada variabel dependen (Nilai Perusahaan).

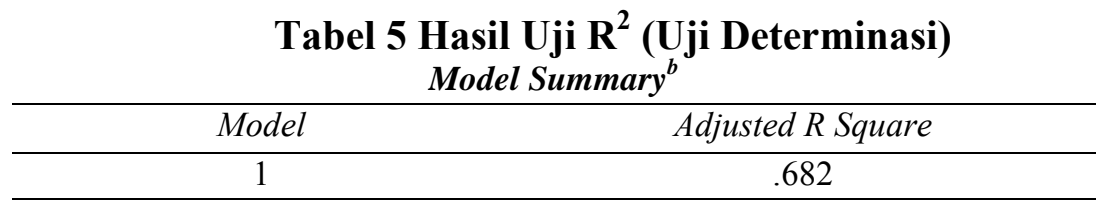

a. Predictors: (Constant), Ukuran Perusahaan, Profitabilitas, Leverage

b. Dependent Variable: Nilai Perusahaan

Sumber: Data sekunder yang telah diolah

Pada tabel 5 hasil uji determinasi diatas dapat menunjukkan bahwa nilai Adjusted $R$ Square $\left(\mathrm{R}^{2}\right)$ adalah sebesar 0.682 atau $68.2 \%$. Hal ini menunjukkan bahwa persentase pengaruh variabel independen (Profitabilitas, Leverage dan Ukuran Perusahaan) terhadap variabel dependen (Nilai Perusahaan) sebesar $68.2 \%$ sisanya sebesar $31.8 \%$ dipengaruhi oleh variabel-variabel lain yang tidak dimasukkan kedalam penelitian ini. Seperti pengaruh kepemilikan saham oleh manajerial, semakin besar kepemilikan saham oleh pihak manajemen maka manajemen cenderung akan mengoptimalkan kinerja dan penggunaan sumber daya sehingga mengakibatkan kenaikan nilai perusahaan. Dan juga pengaruh likuiditas, dimana semakin tinggi likuiditas maka nilai perusahaan tinggi dan semakin rendah likuiditas maka nilai perusahaan rendah. Kemampuan kas yang tinggi akan berdampak terhadap kemampuan perusahaan dalam melunasi kewajiban jangka pendek perusahaan sehingga berdampak positif terhadap nilai perusahaan.

\section{Uji t (Uji Parsial)}

Uji $t$ dapat berguna untuk mengetahui apakah variabel independen atau bebas secara parsial (individual) memiliki pengaruh yang signifikan terhadap variabel dependen atau tidak.

Tabel 6 Hasil Uji t (Uji Parsial)

Coefficients $^{a}$

\begin{tabular}{llccccc}
\hline \multirow{2}{*}{ Model } & \multicolumn{2}{c}{$\begin{array}{c}\text { Unstandardized } \\
\text { Coefficients }\end{array}$} & $\begin{array}{c}\text { Standardized } \\
\text { Coefficients }\end{array}$ & \multirow{2}{*}{ T } & \multirow{2}{*}{ Sig. } \\
\cline { 3 - 5 } & \multicolumn{2}{c}{ B } & Std. Error & Beta & & \\
\hline \multirow{2}{*}{1} & (Constant) & -8.700 & 1.452 & & -5.990 & .000 \\
& Profitabilitas & 7.845 & 1.217 & .569 & 6.448 & .000 \\
& Leverage & -.304 & .402 & -.067 & -.754 & .455 \\
& Ukuran & .331 & .054 & .530 & 6.140 & .000 \\
& Perusahaan & & & & & \\
\hline
\end{tabular}

a. Dependent Variable: Nilai Perusahaan

Sumber: Data sekunder yang telah diolah 
Berdasarkan pada tabel 6 hasil uji t (Uji Parsial) di atas, maka dapat diketahui bahwa variabel profitabilitas memiliki $t_{\text {hitung }}$ sebesar 6.448 sedangkan $t_{\text {tabel }}$ sebesar 2.01537, maka $t_{\text {hitung }}>t_{\text {tabel }}$ yaitu $6.448>$ 2.01537 dengan nilai signifikansi sebesar $0.000<0.05$. Hal ini menunjukkan bahwa $\mathrm{Ho}_{1}$ ditolak dan $\mathrm{Ha}_{1}$ diterima, sehingga dapat disimpulkan bahwa profitabilitas berpengaruh signifikan terhadap nilai perusahaan. Hal ini berarti bahwa besar atau kecilnya tingkat profitabilitas yang diproksikan melalui total laba bersih terhadap total ekuitas, dapat berpengaruh terhadap tinggi rendahnya nilai perusahaan.

Variabel leverage memiliki $t_{\text {hitung }}$ sebesar -0.754 sedangkan $t_{\text {tabel }}$ sebesar 2.01537, maka $t_{\text {hitung }}<\mathrm{t}_{\text {tabel }}$ yaitu -0.754 $<2.01537$ dengan nilai signifikansi sebesar $0.455>0.05$. Hal ini menunjukkan bahwa $\mathrm{Ho}_{2}$ diterima dan $\mathrm{Ha}_{2}$ ditolak, sehingga dapat disimpulkan bahwa leverage tidak berpengaruh secara signifikan terhadap nilai perusahaan.

Variabel ukuran perusahaan memiliki $t_{\text {hitung }}$ sebesar 6.140 sedangkan $t_{\text {tabel }}$ sebesar 2.01537, maka $t_{\text {hitung }}>t_{\text {tabel }}$ yaitu $6.140>2.01537$ dengan nilai signifikansi sebesar $0.000<0.05$. Hal ini menunjukkan bahwa $\mathrm{Ho}_{1}$ ditolak dan $\mathrm{Ha}_{1}$ diterima, sehingga dapat tarik kesimpulan bahwa ukuran perusahaan berpengaruh signifikan terhadap nilai perusahaan.

\section{Model Regresi Berganda}

Analisis regresi linear berganda bertujuan untuk mengetahui apakah ada tidaknya pengaruh variabel independen (profitabilitas, leverage dan ukuran perusahaan) terhadap nilai perusahaan.

\section{Tabel 7 Hasil Uji Regresi Berganda}

\begin{tabular}{clccc}
\multicolumn{4}{c}{ Model } & \multicolumn{3}{c}{ Coefficients $^{\boldsymbol{a}}$} \\
\cline { 3 - 5 } & \multicolumn{2}{c}{$\begin{array}{c}\text { Unstandardized } \\
\text { Coefficients }\end{array}$} & $\begin{array}{c}\text { Standardized } \\
\text { Coefficients }\end{array}$ \\
\cline { 3 - 5 } & (Constant) & -8.700 & Std. Error & Beta \\
\hline 1 & Profitabilitas & 7.845 & 1.452 & \\
& Leverage & -.304 & .402 & .569 \\
& Ukuran Perusahaan & .331 & .054 & -.067 \\
& & &
\end{tabular}

a. Dependent Variable: Nilai Perusahaan

Sumber: Data sekunder yang telah diolah

Dari tabel 7 uji model regresi berganda diatas, maka dapat diperoleh persamaan regresi sebagai berikut :

\section{PEMBAHASAN}

\section{Pengaruh Profitabilitas Terhadap Nilai Perusahaan}

Besar kecilnya tingkat profitabilitas yang diproksikan melalui total laba bersih terhadap total ekuitas, dapat berpengaruh pada tinggi atau

$$
\begin{aligned}
\text { PBV }= & -8.700+7.845 \text { ROE }-0.304 \\
& \text { DAR }+0.331 \text { SIZE }
\end{aligned}
$$

rendahnya nilai perusahaan. Hasil dari penelitian ini memberikan bukti secara empiris bahwa profitabilitas berpengaruh secara signifikan terhadap nilai perusahaan dan juga sesuai dengan hasil penelitian yang telah dilakukan oleh Ju Chen \& Yu Chen (2011), 
Mahendra DJ, dkk (2012), Dewi \& Wirajaya (2013), Rizqia, dkk (2013) serta Nurhayati (2013). Hasil penelitian ini mendukung hipotesis bahwa profitabilitas merupakan pengukuran kemampuan perusahaan dalam memperoleh laba dalam menjalankan operasinya dengan menggunakan ekuitas atau modal. Semakin besar tingkat profitabilitas yang dimiliki oleh suatu perusahaan maka perusahaan tersebut memiliki kinerja yang baik sehingga kemampuan perusahaan dalam membayar dividennya juga baik, hal ini yang dapat menarik para investor untuk menanamkan modalnya kepada perusahaan tersebut sehingga harga saham perusahaan dapat meningkat dan akan memperngaruhi pada kenaikan nilai perusahaan.

\section{Pengaruh Leverage Terhadap Nilai Perusahaan}

Besar kecilnya tingkat leverage yang diproksikan melalui total hutang terhadap total aktiva, tidak berpengaruh pada tinggi rendahnya nilai perusahaan. Hasil dari penelitian ini tidak memberikan bukti secara empiris bahwa leverage memiliki pengaruh signifikan terhadap nilai perusahaan. Hasil penelitian ini sejalan dengan hasil penelitian yang telah dilakukan oleh Ju Chen \& Yu Chen (2011) serta Mahendra Dj, dkk (2012) bahwa leverage tidak memiliki pengaruh terhadap nilai perusahaan. Hasil penelitian ini tidak mendukung hipotesis bahwa perusahaan yang memiliki tingkat hutang yang semakin tinggi akan menurunkan laba perusahaan yang berakibat pada menurunnya minat para investor dalam menanamkan modalnya sehingga harga saham akan mengalami penurunan yang berpengaruh pada menurunnya nilai perusahaan. Dalam prakteknya, meskipun perusahaan didanai oleh hutang dalam menjalankan operasinya dan secara otomatis membuat tingkat resiko yang harus dihadapi oleh perusahaan mengalami peningkatan tetapi investor akan melihat kapan waktu jatuh tempo hutang yang digunakan oleh perusahaan, waktu jatuh tempo hutang yang masih terbilang lama membuat para investor memutuskan untuk menanamkan modalnya dalam perusahaan tersebut sehingga harga saham akan mengalami kenaikan dan berpengaruh pada naiknya nilai perusahaan.

\section{Pengaruh Ukuran Perusahaan Terhadap Nilai Perusahaan}

Besar kecilnya ukuran perusahaan melalui total aset, akan berpengaruh juga pada tinggi rendahnya nilai perusahaan. Hasil penelitian ini memberikan bukti secara empiris bahwa ukuran perusahaan berpengaruh signifikan terhadap nilai perusahaan dan juga sesuai dengan hasil penelitian yang telah dilakukan oleh Nuraina (2012), Rizqia, dkk (2013) serta Nurhayati (2013). Hasil penelitian ini mendukung hipotesis bahwa ukuran perusahaan dapat menunjukan prestasi dari suatu perusahaan, dimana perusahaan yang memiliki ukuran yang besar dianggap mampu mengelolah perusahaan yang baik dan memiliki kinerja yang baik pula, sehingga perusahaan akan lebih mudah menarik investor karena para investor cenderung akan lebih percaya kepada perusahaan yang memiliki ukuran yang besar dengan kinerja yang baik dalam menanamkan modalnya, hal 
ini akan meningkatkan harga saham yang berpengaruh pada meningkatnya nilai perusahaan.

\section{SIMPULAN}

Hasil penelitian ini menunjukkan bahwa :

a. Berdasarkan pada uji simultan (bersama-sama) yang dilakukan, maka profitabilitas, leverage, dan ukuran perusahaan berpengaruh secara signifikan terhadap nilai perusahaan.

b. Berdasarkan pada uji parsial (individual) yang dilakukan, maka profitabilitas dan ukuran perusahaan terbukti memiliki pengaruh yang signifikan positif terhadap nilai perusahaan. Sedangkan leverage tidak terbukti berpengaruh signifikan terhadap nilai perusahaan.

c. Berdasarkan dari uji koefisien determinasi yang dilakukan, maka diketahui bahwa variabel profitabilitas, leverage dan ukuran perusahaan memiliki pengaruh yang cukup besar terhadap nilai perusahaan.

d. Berdasarkan dari hasil penelitian yang dilakukan, maka dapat diketahui bahwa tingkat profitabilitas yang dimiliki oleh perusahaan manufaktur sektor industri dasar dan kimia yang terdaftar pada Bursa Efek Indonesia (BEI) pada tahun 20132014 memiliki pengaruh yang sangat tinggi terhadap nilai perusahaan dibandingkan oleh variabel lainnya (leverage dan ukuran perusahaan).

\section{DAFTAR PUSTAKA}

Allens, J 2014, Laba meningkat disaat turunnya penjualan, saham
SMBR bersiap menurun. Indonesia.

http://vibiznews.com/2014/07/24/ laba-meningkat-disaat-turunnyapenjualan-saham-smbr-bersiapmenurun/

Ardiyos 2010, Kamus besar akuntansi, Citra Harta Prima, Jakarta.

Brealey 2007, Dasar-dasar manajemen keuangan perusahaan, Erlangga, Jakarta.

Brigham \& Houston 2011, Dasar-dasar manajemen keuangan, Salemba Empat, Jakarta.

Dewi, ASM \& Wirajaya, A 2013, 'Pengaruh struktur modal, profitabilitas dan ukuran perusahaan pada nilai perusahaan', E-Jurnal Akuntansi Universitas Udayana, ISSN: 2302-8556, Bali.

Ghozali, I 2011, Aplikasi multivariative dengan program IBM SPSS 19, Universitas

Diponogoro, Semarang.

Harahap, SS 2011, Analisis kritis atas laporan keuangan, Rajawali Pers, Jakarta.

Harahap, SS 2012, Teori akuntansi, Rajawali Pers, Jakarta.

Harjito, A \& Martono 2013. Manajemen keuangan, Ekonisia, Yogyakarta.

Ikatan Akuntansi Indonesia 2013, Standar akuntansi keuangan per 1 Juni 2012, Ikatan Akuntansi Indonesia, Jakarta.

Kasmir 2014, Analisis laporan keuangan, Rajawali Pers, Jakarta.

Li-Ju Chen and Shun-Yu Chen 2011, 'The influence of profitability on firm value with capital structure as the mediator and firm size and industry as moderators', 
Investment Management and Financial Innovations. Vol. 8, Issue 3.

Mahendra, ADj, Artini, LGS \& Suarjaya, AAG 2012, 'Pengaruh kinerja keuangan terhadap nilai perusahaan pada perusahaan manufaktur di bursa efek indonesia', Jurnal Manajemen, Strategi Bisnis dan Kewirausahaan. Vol. 6, No. 2.

Moniaga, F 2013, 'Struktur modal, profitabilitas dan struktur biaya terhadap nilai perusahaan industri keramik, porcelen dan kaca periode 2007-2011', Jurnal $E M B A$, Vol. 1, No. 4, ISSN 23031174.

Nuraina, E 2012, 'Pengaruh kepemilikan institusional dan ukuran perusahaan terhadap kebijakan hutang dan nilai perusahaan', Jurnal Bisnis dan Ekonomi (JBE), Vol. 19, No.12, ISSN: 1412-3126.

Nurhayati, M 2013, 'Profitabilitas, likuiditas dan ukuran perusahaan pengaruhnya terhadap kebijakan dividend dan nilai perusahaan sektor non jasa', Jurnal Keuangan dan Bisnis, Vol. 5, No. 2.

Prasetyorini, BF 2013, 'Pengaruh ukuran perusahaan, leverage, price earning ratio dan profitabilitas terhadap nilai perusahaan', Jurnal Imu Manajemen, Vol 1, No. 1.

Rizqia, DA, Aisjah, S \& Sumiati 2013, 'Effect of managerial ownership, financial leverage, profitability, firm size, and investment opportunity on dividend policy and firm value', Research Journal of Finance and Accounting, Vol. 4, No. 11, ISSN 2222-1697.

Sitanggang, JP 2013, Manajemen keuangan perusahaan lanjutan, Mitra Wacana Media, Jakarta.

Sitanggang, JP 2014, Manajemen keuangan perusahaan, Mitra Wacana Media, Jakarta.

Sjahrial, D \& Djahotman, P 2013. Analisa laporan keuangan. Mitra Wacana Media. Jakarta.

Sujoko \& Ugy, S 2007, 'Pengaruh struktur kepemilikan saham, leverage, faktor intern dan faktor ekstern terhadap nilai perusahaan', Jurnal Manajemen dan Kewirausahaan, Vol. 9, No. 1, Maret 2007: 41-48.

Suwardjono 2010, Teori akuntansi perekayasaan pelaporan keuangan, BPFEYOGYAKARTA, Yogyakarta.

Universitas Pembangunan Nasional "Veteran" 2014, Pedoman Penulisan Karya Ilmiah Bagi Dosen Dan Mahasiswa, Lembaga Penelitian dan Pemberdayaan Masyarakat, Jakarta. 